\title{
Chemical and Physical Characterization of Fly Ash as Geopolymer Material
}

\author{
Puput Risdanareni ${ }^{1,4, *}$ Poppy Puspitasari ${ }^{2,4}$, Ekaputri Januarti Jaya ${ }^{3,4}$ \\ ${ }^{1}$ Department of Civil Engineering, Universitas Negeri Malang, Malang, Indonesia \\ ${ }^{2}$ Departement of Mechanical Engineering, Universitas Negeri Malang, Malang, Indonesia \\ ${ }^{3}$ Departement of Civil Engineering, Institut Teknologi Sepuluh Nopember, Surabaya, Indonesia \\ ${ }^{4}$ Konsorsium Riset Geopolimer Indonesia (KORIGI), Lab Beton dan Bahan Bangunan ITS, \\ Surabaya, Indonesia
}

\begin{abstract}
Research on finding suitable cement substitute material becomes massive due to environmental effect. Geopolymer as inorganic material is potential to be the smart solution to overcome global warming issue. Fly ash is a waste material rich in silica and alumina becomes popular raw material to produce geopolymer. The best properties ofgeopolymer paste come from the high quality of fly ash. Therefore, it is important to investigate various types of fly ash and geopolymer properties. Their chemical and physical properties characterized by XRF, $\mathrm{pH}$ value, XRD and SEM. The results showed that type of fly ash depended on amount of Si-based of Ca-based compound which consisted of spherical morphology. Geopolymer paste produced from the ash with different compound has bulky and irregular shape morphology. The $\mathrm{pH}$ value of each ash has also a correlation with the setting time of fresh paste.
\end{abstract}

\section{Introduction}

Recently, the utilization of cement in construction industry becomes a popular issue due to its environmental effect. Many studies revealed that in its production, portland cement exceeds high number of $\mathrm{CO}_{2}$ to the atmosphere causing global warming [1,2].Geopolymer, an inorganic material synthesized from high silica and alumina materials activated with alkali solution becomes one of the smart solutions to overcome global warming issue due to cement production [3]. Utilizing geopolymer material as construction material such as concrete proved can reduce global warming effect due to its cement use reduction.

Fly ash, waste material which is rich in silica and alumina derived from coal combustion process becomes popular raw material to produce geopolymer materials [4]. ASTM C618 classified fly ash into two categories based on its oxides content of $\mathrm{Si}, \mathrm{Al}$ and $\mathrm{Fe}$ [5]. Fly ash is categorized as class $\mathrm{F}$ for its rich in silica content but fly ash class $\mathrm{C}$ is known to have high calcium content [5]. However, identifying fly ash character becomes more complicated due to its heterogeneous composition and its physical properties. The varying composition of fly ash is depending on type of coal, boiler type, operation condition, post combustion technology and power plant technology [6].

\footnotetext{
${ }^{*}$ Corresponding author: puput.risdanareni.ft@um.ac.id
} 
Research investigation on fly ash characterization conducted by Nurwidayati revealed that mechanical properties of geopolymer paste is strongly influenced by physical and chemical characteristic of fly ash such as fineness, specific surface area and soluble content [7]. Other study by Tajunnisa concluded that similar mechanical properties of geopolymer paste were less influenced by ashes used from the same class of fly ash [8].

Several testing such as XRF, $\mathrm{pH}, \mathrm{XRD}$ and SEM was conducted in order to identify physical and chemical character of fly ash. Using XRF test, chemical composition of fly ash that can be used to categorize them into class $F$ or class $C$ could be ascertain [9]. Research conducted by Antoni stated that degree of acid or $\mathrm{pH}$ from fly ash plays an important role in setting time of geopolymer paste. Higher $\mathrm{pH}$ level of fly ash induces faster setting time of geopolymer paste $[10,11]$. XRD test was performed in order to discover crystalline mineral component of fly ash [12]. On the other hand, SEM is required to analyze the shape, surface and internal structure of fly ash particle $[6,12]$. Previous research explained that chemical composition, morphology and crystalline mineral component of fly ash influenced mechanical and physical properties of its geopolymer paste such as compressive strength and setting time [13-15].

In general, it is summarized that chemical and physical characterization on fly ash are required to predict and control mechanical and physical properties of geopolymer paste. Therefore, the characterization data of fly ash is necessaryto make an accurate mix design of geopolymer paste and concrete [9].

\section{Chemical characterization}

\subsection{XRF test}

XRF test was conducted for chemical composition of fly ash [9]. The percentage of important compound such as silica, alumina, calcium and ferrite were determined with this testing. Furthermore, identifying percentage of calcium in fly ash, categorization fly ash as class $\mathrm{F}$ (low calcium) or C (high Calsium) referred to ASTM C618 were assessed. Research conducted by Antoni discovered that $\mathrm{CaO}$ content in fly ash plays important role in physical properties of geopolymer paste. High $\mathrm{CaO}$ content in fly ash induces geopolymer paste set rapidly [16]. XRF testing result of fly ashes from several power plants and cement industries is listed in Table 1 and Table 2.

Table 1. Chemical Composition of Fly Ash from Paiton, Rembang and TanjungJati, Indonesia [10]

\begin{tabular}{|c|c|c|c|c|c|c|c|c|c|}
\hline Code & $\mathrm{SiO}$ & $\mathrm{Al}_{2} \mathrm{O}_{3}$ & $\mathrm{CaO}$ & $\mathrm{Fe}_{2} \mathrm{O}_{3}$ & $\mathrm{~K}_{2} \mathrm{O}$ & $\mathrm{MgO}$ & $\mathrm{SO}_{3}$ & $\mathrm{LOI}$ & $\begin{array}{c}\mathrm{SiO}_{2}+\mathrm{Al}_{2} \mathrm{O}_{3}+ \\
\mathrm{Fe}_{2} \mathrm{O}_{3}\end{array}$ \\
\hline $\mathrm{Y} 11.2$ & 30.78 & 17.87 & 15.47 & 15 & 1.32 & 6.45 & 1.32 & 0.49 & 63.65 \\
\hline $\mathrm{J} 10.6$ & 38.24 & 15.28 & 9.15 & 24.28 & 0.78 & 5.19 & 0.61 & 3.9 & 77.8 \\
\hline P 10.3 & 51.03 & 25.13 & 5.49 & 9.66 & 1.58 & 3.25 & 0.51 & 1.44 & 85.82 \\
\hline Y 9.8 & 51.12 & 18.9 & 5.54 & 17.71 & 0.82 & 3.17 & 0.47 & 6.96 & 87.73 \\
\hline R 9.6 & 50.14 & 29.08 & 4.03 & 9.66 & 1.53 & 1.11 & 0.77 & 0.63 & 88.88 \\
\hline
\end{tabular}


Table 2. Chemical Composition of Fly Ash from PT. Surya Beton and Semen Indonesia [8]

\begin{tabular}{|c|c|c|c|c|c|c|c|c|c|c|}
\hline Code & $\mathrm{SiO}$ & $\mathrm{Al}_{2} \mathrm{O}_{3}$ & $\mathrm{CaO}$ & $\mathrm{Fe}_{2} \mathrm{O}_{3}$ & $\mathrm{~K} 2 \mathrm{O}$ & $\mathrm{MgO}$ & $\mathrm{Na}_{2} \mathrm{O}$ & $\mathrm{P}_{2} \mathrm{O}_{5}$ & $\mathrm{SO}_{3}$ & $\begin{array}{c}\mathrm{SiO}_{2}+\mathrm{Al}_{2} \mathrm{O}_{3}+ \\
\mathrm{Fe}_{2} \mathrm{O}_{3}\end{array}$ \\
\hline $\mathrm{SB} 1$ & 37.45 & 24.49 & 15.73 & 11.79 & 1.13 & 0.32 & 0.99 & 2.52 & 0.80 & 73.73 \\
\hline $\mathrm{SB} 2$ & 38.76 & 29.43 & 4.05 & 18.43 & 0.88 & 0.01 & 0.88 & 2.19 & 0.67 & 86.62 \\
\hline SB3 & 39.16 & 31.03 & 10.26 & 11.60 & 0.46 & 0.72 & 0.68 & 2.27 & 0.70 & 81.79 \\
\hline SB4 & 39.11 & 30.92 & 10.04 & 11.93 & 0.47 & 0.62 & 0.69 & 2.30 & 0.69 & 81.96 \\
\hline SI1 & 41.17 & 34.48 & 1.89 & 11.54 & 1.05 & 1.74 & 0.96 & 2.04 & 0.65 & 87.19 \\
\hline SI2 & 34.65 & 22.55 & 15.24 & 12.52 & 1.31 & 6.82 & 1.58 & 3.23 & 1.17 & 69.72 \\
\hline
\end{tabular}

Table 1 shows that fly ash type Y11.6 is categorized as class $\mathrm{C}$ due to its high calcium content (more than $10 \%$ ), while the rest of samples are categorized as class $\mathrm{F}$ because they contain silica oxide, alumina and ferrite more than $70 \%$.

Listed in Table 2, since its contain silica oxide, alumina and hematite less than $70 \%$, fly ash SI 2 is categorized as class $\mathrm{C}$, while the rest of the samples are categorized as class $\mathrm{F}$. There is an interesting part of Table 2. Sample SB1, SB3, and SB4 have calcium content more than $10 \%$ as categorized as class $\mathrm{C}$. However, they contain silica, alumina and hematite more than $70 \%$ which meet criteria as class F.

The compressive strength test result of geopolymer paste produced from fly ash from Table 2 is presented at Figure 1.

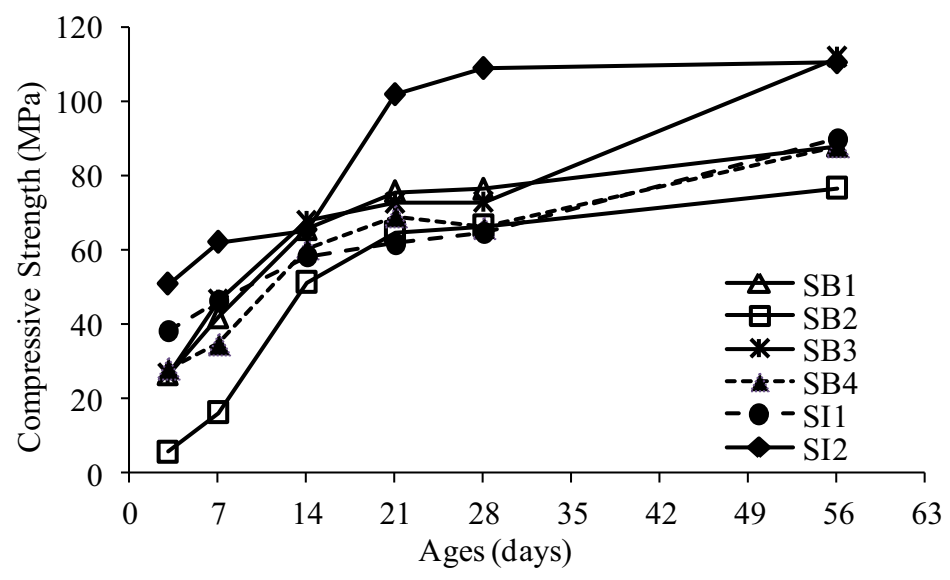

Fig. 1. Compressive Strenghtof Geopolymer Paste at Different Ages [8]

It shows that sample SI2 has high compressive strength although it contains less $\mathrm{CaO}$ as compared to SB1. Previous research stated that high $\mathrm{CaO}$ content in fly ash resulted high compressive strength on geopolymer paste [10]. This might occur due to ash's particle size and reactivity of silica content as stated by Fernandez that the key factors of fly ash potential reactivity are: the reactive silicacontent, the vitreous phase content and the particle size distribution [17]. 


\section{$2.2 \mathrm{pH}$ test.}

Research conducted by Antoni revealed that $\mathrm{pH}$ value of fly ash influence the setting time of geopolymer paste [11]. The $\mathrm{pH}$ value was tested by dissolving fly ash into distilled water followed with $\mathrm{pH}$ measurement. Fly ash with $\mathrm{pH}$ value ranged from 8 to 11 tends to experience rapid setting [14]. In addition, $\mathrm{pH}$ value of fly ash has closely correlation with its $\mathrm{CaO}$ content. High $\mathrm{CaO}$ content in fly ash resulted in higher $\mathrm{pH}$ value [10].Correlation between $\mathrm{pH}$ value and $\mathrm{Ca}$ content of fly ash to initial setting time and compressive strength of geopolymer paste is presented at Table 3 .

Table 3.The Effect $\mathrm{pH}[10,11]$

\begin{tabular}{|c|c|c|c|c|}
\hline $\begin{array}{c}\text { Sample } \\
\text { Code }\end{array}$ & $\mathrm{pH}$ Level & $\begin{array}{c}\text { Ca Content } \\
(\% \text { mass })\end{array}$ & $\begin{array}{c}\text { Initial setting time } \\
\text { (minutes) }\end{array}$ & $\begin{array}{c}\text { Compressive Strength } \\
(\mathrm{MPa})\end{array}$ \\
\hline Y 11.2 & 11.2 & 15.47 & 18 & 98 \\
\hline J 10.6 & 10.6 & 9.15 & 62 & 58 \\
\hline P 10.3 & 10.3 & 5.49 & 110 & 40 \\
\hline Y 9.8 & 9.8 & 5.54 & 120 & 47 \\
\hline R 9.6 & 9.6 & 4.03 & 42 & 58 \\
\hline
\end{tabular}

High $\mathrm{CaO}$ content causes not only polymerization reaction but also hydration reaction thatimproves the compressive strength [10]. However, one sample containing less $\mathrm{CaO}$ (R9.6) shows rapid setting time. It might have correlation with its physical shape or other contaminant from the coal origin which is discussed later in this paper.

\section{Physical characterization}

\subsection{XRD test.}

$\mathrm{X}$-Ray diffraction with $\mathrm{CuK} \alpha$ radiation, $\mathrm{K} \alpha=0.89$ and wavelength $\lambda=1.54056 \AA$ was used to determine the crystal structure [18]. Fig. 2 shows the XRD pattern of geopolymer compared between Indonesian Fly Ash and Japanese Fly Ash. The results show that both ash types have a same major peak of crystalline phase i.e quartz $\left(\mathrm{SiO}_{2}\right)$. Besides, Japanese fly ash also contained crystalline phase of hematite $\left(\mathrm{Fe}_{2} \mathrm{O}_{3}\right)$, and mullite $\left(3 \mathrm{Al}_{2} \mathrm{O}_{3} \cdot 2 \mathrm{SiO}_{2}\right)$. In addition, Indonesian fly ash also contained srebrodolskite $\left(\mathrm{Ca}_{2} \mathrm{Fe}_{2} \mathrm{O}_{5}\right)$, magnetite $\left(\mathrm{Fe}_{3} \mathrm{O}_{4}\right)$, anhydrite $\left(\mathrm{CaSO}_{4}\right)$ and lime $(\mathrm{CaO})[8]$.

The second major peak presents that both of Fly Ash contain Fe-based material with different oxidation state (hematite and magnetite). It seems that Indonesian Fly Ash is easier to oxidize compared to Japanese Fly Ash. Indonesian Fly Ash also contains more $\mathrm{SiO}_{2}$ and $\mathrm{CaO}$ than Japanese Fly Ash although the major peak happened at the similar 2 theta degree at 20-30. Previous studies informed that quartz identified as peak phase of geopolymer crystal occured in the range degree of 20-30 with the intensity ranged 1200-1800 [8]. 


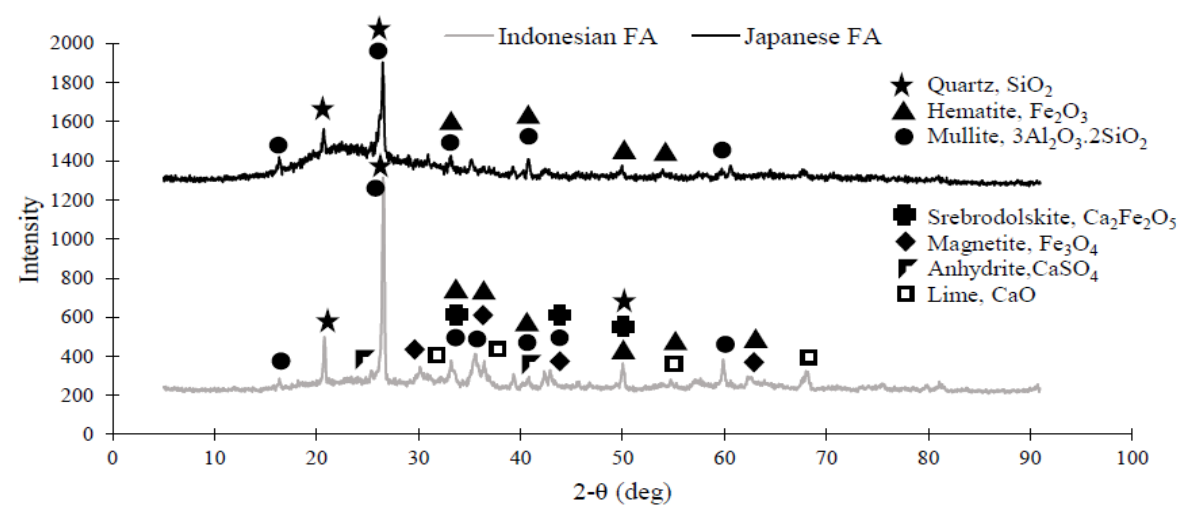

Fig.2. XRD Pattern of Indonesian and Japanese Fly Ash [8]

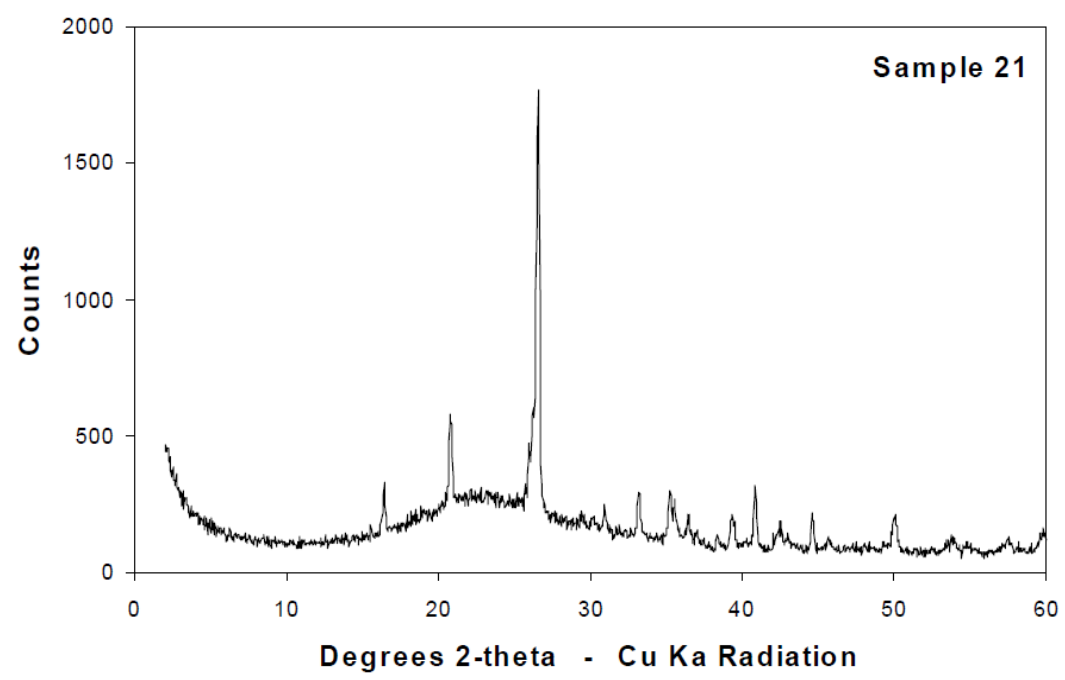

Fig. 3. XRD pattern of Australian Fly Ash [12]

Figure 3, illustrates the XRD pattern of Australian Fly Ash with major peak at 20-30 two theta degree. It was characterized using Philips X'pert Diffracto meter. The scans were run from 2 to $60^{\circ} 2 \theta$, with increments of $0.04^{\circ}$ and counting time of 2 seconds per step [13]. The peaks consist of quartz, mullite, magnetite, hematite, calcium aluminate, and glass.

The previous research concluded that sharp major peak occur at small degree of 2 theta, that means the distance of particles is closer. This is due to large particle size and small surface area. Small surface area resulted less mechanical properties [7].

Australian, Indonesian and Japanese fly ash as presented in Figure 2 and Figure 3 was categorized as fly ash class F due to its high silica and alumina content. Based on their XRD test, all specimens perform a quartz as their peak phase. Therefore, it can be concludes that fly ash class $\mathrm{F}$ which has high silica and alumina content will perform quartz compound as their peak phase. 


\subsection{SEM test}

Scanning Electron Microscope (SEM) was conducted in order to investigate the morphology of particles [17]. In addition, a morphology particle shape data can be used for predicting the mechanical and physical properties of material [12]. The results of SEM test for several fly ashes obtained from different sources are illustrated in Figure4 and Figure 5.
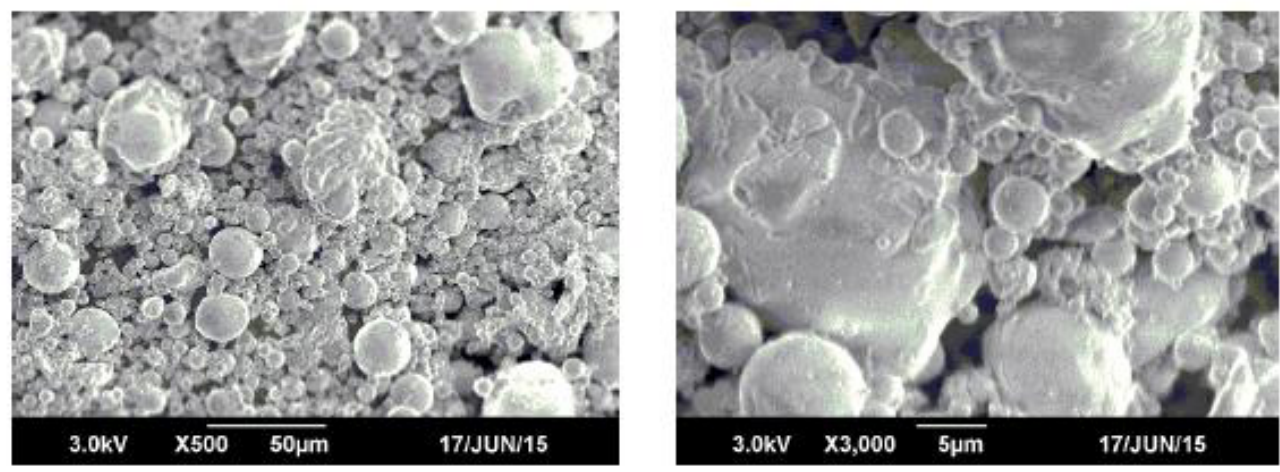

Fig.4. SEM results of Indonesian Fly Ash [8]
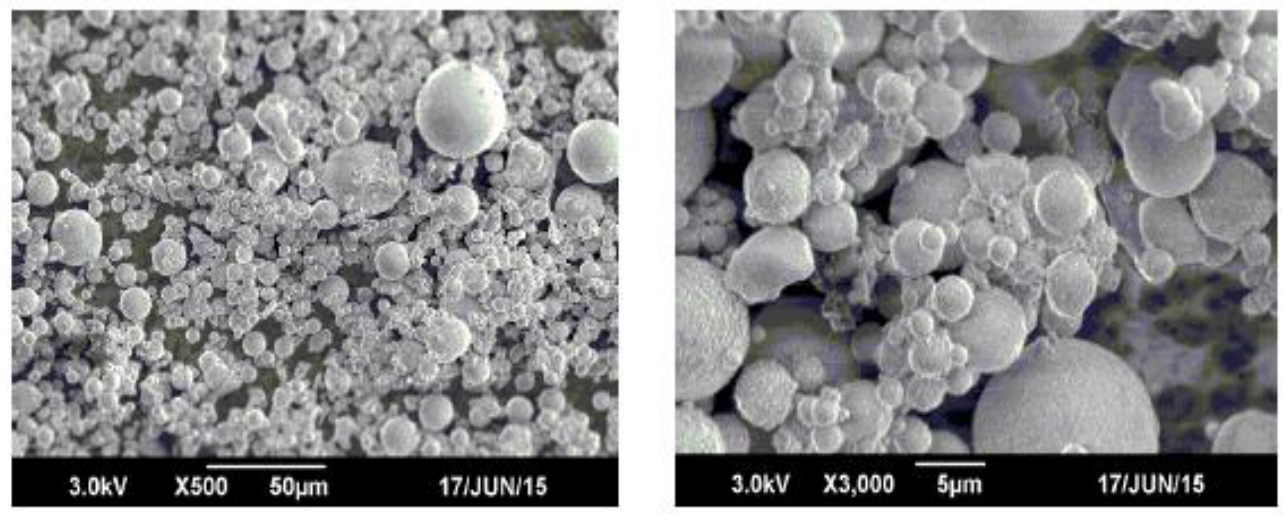

Fig. 5. SEM results of Japanese Fly Ash [8]

In Figure 4 and Figure 5, the shape of fly ash particles aregenerally spherical shape.Fly ash obtained from Indonesia power plant has irregular shape pattern (bulky) compared to Japanese fly ash. However, the result found that geopolymer paste produced from Indonesian fly ash has higher compressive strength compared to whose produced from Japanesefly ash.This condition occurs because the bulky particle shape of Indonesian fly ash has short particle distance compared to a homogeneous Japanesefly ash.Previous study by Fernandez stated that particles size distribution of fly ash play an important role in mechanical properties of geopolymer paste [17]. Hence, morphology of several fly ash and its geopolymer paste are illustrated at Figure 6 and Figure 7.

The morphology of fly ash and geopolymer paste showed in Figure 6 are clearly different in their shape. Fly ash obtained from Texas categorized as class $\mathrm{C}$ has spherical shape particles while geopolymer paste is in bulk structure. Spherical shape of fly ash seems heterogenic and has various distances between particles due to large difference of particle diameter. 
In Figure 7, fly ash obtained from Tarong categorized as class F and its geopolymer paste shared a similar particle's morphology. Additionally, the coating layer at the surface of fly ash particles is occurs at morphology of geopolymer paste. This explains that geopolymerization reaction between fly ash and alkali solution only occurs at the surface of fly ash particles [13]. Therefore, it proves that the short distance between particles improves coated and linked form in geopolymer paste.
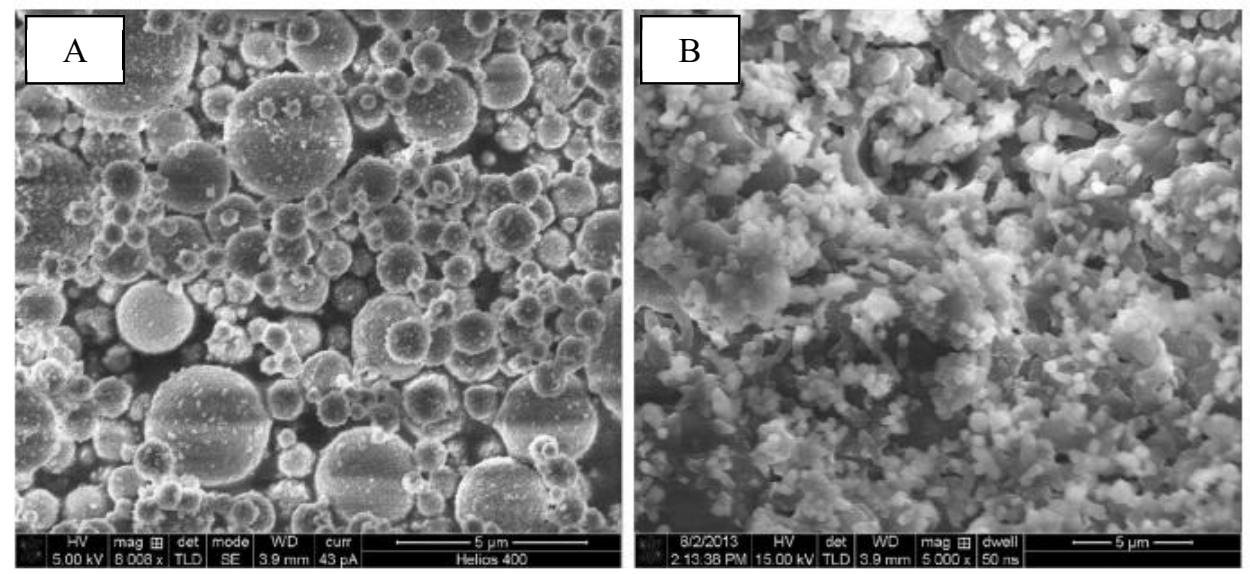

Fig. 6. Morphology of Texas Fly Ash (A) and Geopolymer Paste (B) [19]
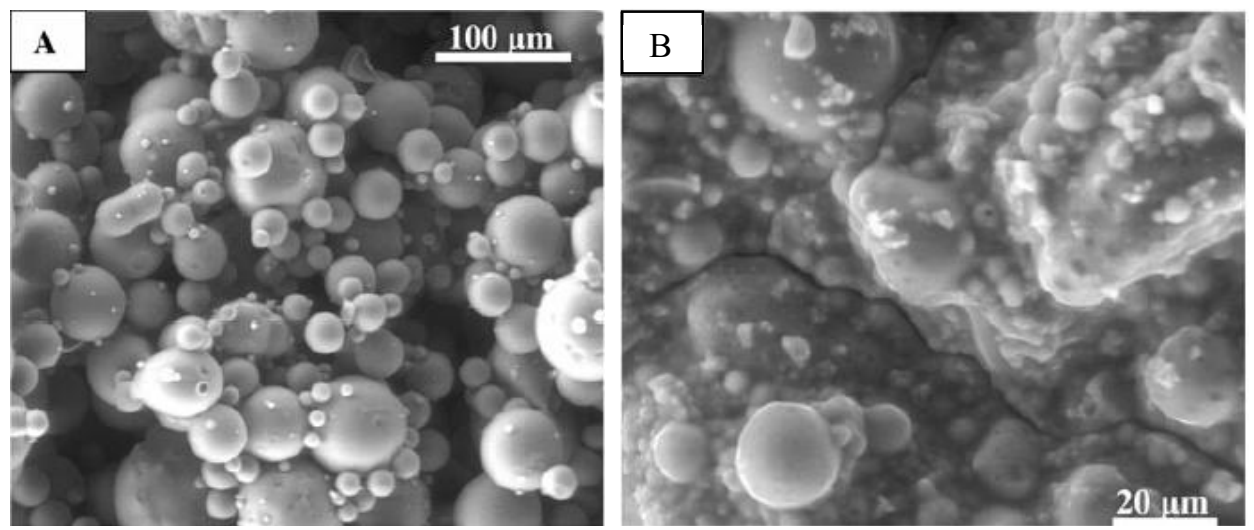

Fig.7. Morphology of TarongFly Ash (A) and Geopolymer Paste (B) [13]

The research conducted by Tajunnisa stated that more irregular shape particles required more water in mixing geopolymer paste[8]. With the purpose of produce geopolymer paste, water content is represented by alkali solution. It is also concluded that concentration and composition of alkali solution plays an important role in developing mechanical properties of geopolymer paste [20-22].

\section{Summary}

The various type of fly ash resulted in different characterization results. Japanese fly ash consists of Ca-based compound and magnetite, Indonesian fly ash consists of Si-based compound and hematite, while Australian FA consists of quartz, hematite, magnetite, and 
$\mathrm{CaO}$. The $\mathrm{pH}$ value and $\mathrm{CaO}$ content of fly ash influences setting time of geopolymer paste. All diffraction patternsof fly ash showed the major peak at 20-30 two theta degree. The morphology of fly ash particles was mostly in spherical shape while geopolymer paste as their product was bulky irregular shape. Distance of particles contributed by their size is one of important factors to increase mechanical strength of geopolymer paste.

\section{References}

1 C.A. Hendriks, Proceedings of the 4th International Conference on Greenhouse Gas ControlTechnologie (Interlaken, Austria, 1998)

2 E. Gartner, Cem. Concr. Res., 34, 1489 (2004)

3 J. Davidovits, Proceeding First International Conference on Alkali Cement and Concrete (1994)

4 D.Hardjito, Studies on Fly Ash-Based Geopolymer Concrete (Curtin Univ of Technology, 2005)

5 American Society for Testing and Materials, ASTM C618, Annual Book of ASTM Standard, (West Conshohocken, US, 2004)

6 B.G. Kutchko, A.G. Kim, Fuel, 85, 2537 (2006)

7 R. Nurwidayati, M.B Ulum, J.J Ekaputri, Triwulan, P. Suprobo, Mater. Sci. Forum, 841, 118 (2016)

8 Y. Tajunnisa, M. Sugimoto, T. Sato, J.J. Ekaputri, M.Shigeishi, International Conference and Exhibition of Structural Faults and Repair 2016 (Edinburg, 2016)

9 J. Van Jaarsveld, J. Van Deventer, G. Lukey, Mater. Lett., 57, 1272 (2003)

10 Antoni, S.W. Wijaya, D. Hardjito, Mater. Sci. Forum, 841, 90 (2016)

11 Antoni, S.W. Wijaya, D. Hardjito, Mater. Sci. Forum, 841, 98 (2016)

12 C.R. Ward, D. French, WOCA (Lexington, Kentucky, USA, 2005)

13 J. Duchesne, L. Duong, T. Bostrom, R. Frost, Waste Biomass Valori, 1, 367 (2010)

14 J.J. Ekaputri, Triwulan, K.A. Priadana, T.E. Susanto, S. Junaedi, The 2013 World Congress on Advances in StructuralEng and Mech (ASEM13) (Jeju, Korea, 2013)

15 J.J. Ekaputri, M.B. Ulum, Triwulan, R. Bayuaji, T.E. Susanto, M.M.A.B. Abdullah, AMM, 754, 320 (2015)

16 Antoni, R. Gunawan, D. Hardjito, AMM, 815, 153 (2015)

17 A. Fernandez Jimenez, A. Palomo, Fuel, 82, 2259 (2003)

18 N. Yahya, P. Puspitasari, J. Nano Res., 21, 131 (2013)

19 A.R. Kotwall, Y.J. Kim, J. Hu, V. Sriraman, International Journal of Concrete Structures and Materials, 9, 35 (2014)

20 P. Risdanareni, J.J Ekaputri, Triwulan, Mater. Sci. Forum 803, 125 (2015)

21 A.N. Hashim, K. Hussin, N. Begum, M.M.A.B. Abdullah, K.A. Razak, J.J. Ekaputri, AMM, 754, 300 (2015)

22 J.J. Ekaputri, Triwulan, S. Junaedi, H. Fansuri, R. Bayuaji, Mater. Sci. Forum, 803, 63 (2015) 